\title{
STUDI GERAK ANIMASI CARTOONY SEBAGAI PERANCANGAN ANIMASI PENDEK BERTEMA CYBERBULLYING
}

\author{
Lisa Tanadi ${ }^{1}$, Frans Santoso $^{2)}$ \\ School of Design, Universitas Bina Nusantara \\ Email: lisa.tanadi@binus.ac.id
}

\begin{abstract}
Abstrak
Dunia perfilman, animasi dengan gaya cartoony memiliki pesonanya sendiri. Dimana kita bisa mencurahkan segala macam imajinasi kita ke dalam bentuk visual yang diluar dugaan ekspektasi dari penonton. Dalam pengerjaan film animasi, 12 prinsip animasi merupakan hal yang penting. Saat ini kita tinggal pada zaman di mana internet seolah menjadi kebutuhan primer manusia karena memenuhi hampir seluruh ruang kehidupan mereka. Kehidupan modern telah menjadi lebih mudah berkat kontribusi besar teknologi internet untuk komunikasi dan berbagi informasi. Meskipun internet memiliki banyak manfaat dan sisi positif, ada berbagai dampak negatif dari internet itu sendiri. Seperti contohnya cyberbullying yang hingga saat ini masih bermunculan dan bahkan memakan korban. Maka dari itu tujuan dari penelitian untuk mempelajari gerak cartoony sebagai perancangan di dalam film animasi pendek bertema cyberbullying. Untuk mendapat hasil studi gerak dan visual sesuai dengan tujuan tersebut, metode penelitian yang akan digunakan untuk pencarian data dalam kajian ini adalah melalui literatur yang bersangkutan, observasi dan wawancara. Output yang dihasilkan berupa workbook visual yang akan digunakan untuk keperluan tugas akhir dalam merancang animasi pendek.
\end{abstract}

Kata Kunci: Animasi pendek, Cartoony, Cyberbullying, Prinsip Animasi, Workbook.

\begin{abstract}
In the world of film, animation with cartoony style has its own charm. Where we can pour all kinds of our imagination into a visual form that is beyond the expectations of the audience. In making animated films, 12 principles of animation are important. Today we live in an age where the internet seems to be the primary need of humans because it fills almost all of their life spaces. Modern life has become easier thanks to the great contribution of internet technology to communication and information sharing. Although the internet has many benefits and positive sides, there are various negative effects of the internet itself. For example, cyberbullying, which until now is still emerging and even taking victims. Therefore, the aim of this research is to study cartoony motion as a design in a cyberbullying themed animated short film. To get the results of the motion and visual studies in accordance with these objectives, the research method that will be used to search the data in this study is through the relevant literature, observation and interviews. The resulting output is in the form of a visual workbook that will be used for the purposes of the final project in designing a short animation.
\end{abstract}

Keywords: Short animation, Cartoony, Cyberbullying, Animation Principles, Workbook. 


\section{PENDAHULUAN}

Film animasi merupakan hal yang lazim di kalangan masyarakat. Film serta series animasi sudah banyak ditampilkan di layar kaca lebar maupun di televisi sehingga banyak kalangan yang sudah menonton hingga pada akhirnya menikmati animasi. Di Indonesia sendiri sudah mulai terlihat dan berdirinya studio animasi beberapa tahun kebelakang ini. Mulai dari studio animasi 2D, 3D maupun CGI. Selain itu juga beberapa tahun belakang ini, animasi dari Indonesia mulai disorot oleh kacah international. Maka dari itu penulis tertarik untuk membuat Style animasi berdasarkan film animasi luar negeri. Penulis ingin menirukan gaya animasinya yang cartoony kedalam riset animasi penulis. Animasi banyak disukai penonton karena mampu membangkitkan mood. Selain sebagai hiburan animasi juga digunakan sebagai media penyampaian informasi. Selain edukatif, animasi juga dapat digunakan untuk menyampaikan ide-ide yang susah untuk dijelaskan di dunia nyata. Perkembangan animasi seiring dengan perkembangan dunia perfilman.

Animasi mulai dikenal secara luas sejak populernya media televisi hingga saat ini populernya internet yang dipakai oleh hampir semua orang. Saat ini kita tinggal pada zaman di mana internet seolah menjadi kebutuhan primer manusia karena memenuhi hampir seluruh ruang kehidupan mereka. Manfaat internet tak hanya sebatas pada akses komunikasi dan informasi. Kini manfaat internet telah merambah pada sektor ekonomi, sosial, hiburan, hingga keamanan. Meskipun internet memiliki banyak manfaat dan sisi positif, ada berbagai dampak negatif dari internet itu sendiri. Seperti contohnya cyberbullying yang yang hingga saat ini masih bermunculan dimana-mana. Menurut survei yang dilakukan oleh Ipssos pada 18.687 warga di 24 negara, termasuk diantaranya Indonesia, juga menemukan bahwa satu dari delapan orang tua menyatakan anak mereka pernah menjadi korban pelecehan dan penghinaan melalui media online. Lebih jauh, penelitian tersebut mengungkap bahwa sebanyak $55 \%$ orang tua menyatakan mereka mengetahui seorang anaknya mengalami cyberbullying (Napitupulu, 2012). Hal lain yang menyebabkan cyberbullying menjadi masalah yang serius karena pada bullying, biasanya ia terjadi pada waktu jam sekolah, sementara untuk cyberbullying, ini bisa terjadi selama 24 jam (Besley, 2009). Remaja dapat menjadi korban cyberbullying kapan saja dan di mana saja. Ia dapat dirundung oleh temannya setelah jam sekolah berakhir (Griezel, Craven, Yeung, \& Finger, 2008). Termasuk saat mereka sedang sendirian di dalam kamar mereka. Cyberbullying sendiri memiliki berbagai tipe dan dampak yang tidak bisa dianggap remeh. Hingga saat ini cyberbullying telah memakan korban, dan dari situlah penulis tergerak sebagai orang yang sering menggunakan media sosial dan menyaksikan berbagai tindakan cyberbullying, penulis ingin membuat animasi pendek bertemakan cyberbullying untuk mengajak penonton untuk menghentikan cyberbullying.

Dalam penelitian riset kali ini bertujuan untuk mempelajari gerak cartoony sebagai perancangan di dalam film animasi pendek bertema cyberbullying. Untuk mendapat hasil studi gerak dan visual sesuai dengan tujuan tersebut, metode penelitian yang akan digunakan untuk pencarian data dalam kajian ini adalah melalui literatur yang bersangkutan, observasi dan wawancara. Output yang dihasilkan berupa workbook visual yang diharapkan dapat berguna untuk keperluan tugas akhir dalam merancang film animasi pendek.

Pada buku Cartoon Animation oleh Preston Blair membagikan pengetahuan praktisnya yang luas untuk menjelaskan dan mendemonstrasikan banyak teknik animasi kartun dan juga membahas poin-poin penting dari menganimasikan karakter, termasuk membuat pose karakter kunci dan di antara karakter. Preston Blair menunjukkan bagaimana membangun karakter kartun asli, mengembangkan bentuk, kepribadian, ciri, dan tingkah laku karakter. Di buku ini ia juga menjelaskan dengan jelas tentang berbagai topik teknis, termasuk pola timing dan spasi, gambar tata letak latar belakang, storyboard kartun, dan sinkronisasi kamera, latar belakang, karakter, suara, dan musik.

Animasi dengan gaya animasi cartoony sudah sering kita temui pada animasi 2D sejak awal-awal serial animasi muncul di televisi. Dan untuk saat ini sudah mulai dikembangkan penggunaannya ke dalam karakter 3D. Di Indonesia sendiri pembuatan animasi karakter 3D sudah semakin berkembang dengan bermunculannya berbagai studi animasi di mancanegara. 
Dari hasil pencarian, penulis berpandangan bahwa animasi dengan gaya cartoony pada karakter 3D di Indonesia masih kurang menonjol. Banyak yang menggunakan gaya animasi organik seperti Disney. Akan tetapi karena sumber daya manusia yang kurang memadai, hasil dari kebanyakan animasi tidak sebagus yang diharapkan, dan menjadi floaty atau jerky. Sudah ada beberapa buku maupun blog di internet yang sudah membahas gaya animasi cartoony pada karakter 3D akan tetapi semua yang penulis temui ditulis oleh orang dari luar negeri. Selain menghibur, gaya animasi 3D dapat membuat karakter tersebut semakin appealing dengan gaya squash and strecth yang dilebih-lebihkan. Dari sini animator dapat lebih bebas dan mengembangkan kreativitasnya terhadap gerak pada karakter 3D.

\section{METODE PENELITIAN}

Metode kualitatif adalah metode penelitian yang digunakan untuk meneliti pada kondisi objek yang alamiah, dimana peneliti adalah sebagai instrumen kunci, teknik pengumpulan data dilakukan secara gabungan, analisis data bersifat induktif, dan hasil penelitian kualitatif jauh lebih menekankan makna daripada generalisasi.

\section{Teknik Pengumpulan Data}

Dari literatur dengan pembacaan literatur-literatur yang mendukung. Salah satunya adalah studi dokumen dilakukan dengan mengkaji dokumen-dokumen terkait topik penelitian. Dokumen tersebut dapat berupa surat, arsip foto, notulen rapat, jurnal, buku harian, dan lainlain.

Dari study existing yang merupakan pengkajian dari karya-karya yang sudah ada sebelumnya. Dalam studi existing kita melakukan observasi, yaitu teknik yang dipakai untuk mengumpulkan data penelitian lewat pengamatan dan pengindraan. Peneliti kemudian membuat laporan berdasarkan apa yang dilihat, didengar, dan dirasakan selama observasi. Observasi dilakukan untuk mendapatkan gambaran yang lebih nyata dan detail mengenai suatu peristiwa atau kejadian. Dan juga penulis mewawancarai beberapa narasumber yang dinilai dapat memberikan informasi yang berguna untuk membantu perancangan animasi film pendek.

\section{Metode Produksi}

Untuk memproduksi penelitian ini, penulis membuat pipeline dalam pembuatan agar rencana produksi tersusun dengan rapi. Metode produksi animasi ini adalah dengan teknik digital dalam bentuk 3D. Dalam produksi animasi, dibagi menjadi 3 tahapan penting, yaitu Pre Produksi,

Produksi, dan Post produksi. Pre Produksi adalah tahap sebelum mulainya animasi itu dibuat, seperti perancangan desain karakter, dan jalur cerita. Produksi adalah tahap dimana kita memulai pembuatan animasi seperti modelling, animating serta rendering. Dan di tahap akhir ada post produksi yaitu tahap compositing dan final output.

\section{Identifikasi Masalah}

Penulis melihat bahwa maraknya cyberbullying masih ada dimana-mana. Yang membuat khawatir penulis adalah dampak yang diberikan cyberbullying tidak bisa dianggap enteng. Maka dari itu penulis ingin mengedukasikan penonton bahwa cyberbullying akan memberikan lebih banyak dampak buruk dengan cara melalui story-telling di film animasi pendek. Semoga animasi ini selain bisa menghibur penonton juga bisa ikut sekaligus mengedukasi.

\section{Ide Cerita}

Diawali dengan terinspirasi kasus cyberbullying yang nyata adanya dimana-mana, dan juga dari serial animasi Spookiz dengan gaya animasinya yang cartoony membuat animasi ini menjadi menarik dan appealing. Selain itu setiap karakter yang memiliki keunikannya masingmasing membuat penulis tertarik untuk membuat animasi dengan gaya cartoony yang masih jarang ditemukan di animasi karya Indonesia sendiri. Penulis ingin memberikan cerita yang 
mengedukasi serta menghibur untuk semua kalangan, sehingga bisa dinikmati oleh seluruh keluarga.

\section{Pengumpulan Data}

Data dikumpulkan dari hasil observasi dan dokumen berserta literatur. Dengan ini penulis dapat mengumpulkan banyak data baik secara langsung maupun tidak langsung. Penggunaan teknik dokumen ini digunakan untuk membantu pengumpulan data terhadap wilayah yang tidak dapat dijangkau oleh penulis. Observasi dilakukan untuk mendapatkan gambaran yang lebih nyata dan detail mengenai suatu peristiwa atau kejadian dan hasilnya dapat diaplikasikan pada karya penulis.

\section{Menyusun Cerita}

Dari hasil pengamatan dan pengumpulan data, penulis mencoba menuliskan cerita yang mengedukasi dan menghibur sehingga bisa dinikmati oleh semua umur. Dengan menargetkan cerita untuk semua umur, akan lebih banyak menarik penonton, karena dengan begitu tidak ada batasan bagi para penonton. Bagi para penonton yang tidak dapat memetik pesan dari cerita tersebut, seperti contohnya anak balita yang masih belum dapat memahami, diharapkan bisa terhibur dari animasinya sendiri, baik secara visual maupun dari gerakan animasinya. Dan bagi penonton yang bisa memetik pesan dari animasi yang akan dibuat ini, penulis berharap dapat mengedukasi tentang bahayanya cyberbullying. Dan membantu untuk menghentikan cyberbullying terjadi lebih jauh lagi.

\section{Desain Karakter}

Penulis membuat karakter dan juga environment yang akan nanti dibuat berdasarkan ide cerita yang sudah dibuat dan mencocokkannya dengan gaya animasi cartoony. Penulis membuat desain karakter berdasarkan literatur yang sudah ada yang membahas mengenai makna di setiap bentuk, garis dan juga warna. Desain karakter diharapkan dapat secara tidak langsung menggambarkan karakteristiknya.

\section{Kajian Literatur Animasi}

Kata animasi berasal dari kata kerja dalam bahasa latin "animare", yang berarti "menghidupkan" atau "memberi nafas" (Wright, 2005). Animasi adalah film yang berasal dari gambar-gambar yang diolah sedemikian rupa hingga menjadi sebuah gambar bergerak (Bambi Bambang Gunawan, 2013:26). Kata animasi sering diartikan sebagai menghidupkan dari sesuatu benda mati atau benda statis yang kemudian bisa menciptakan gerak atau kesan bergerak (Gatot Prakosa, 2010:23.) Maka bisa disimpulkan bahwa animasi didefinisikan sebagai seni atau teknik yang memberi gerak atau menghidupkan suatu objek diam atau mati sehingga terkesan terlihat hidup.

\section{Prinsip Dasar Animasi}

Penemuan animasi tidak terlepas dari penemuan prinsip dasar animasi. Dalam pembuatan animasi sendiri, ada 12 prinsip animasi yang diperkenalkan oleh animator Disney, Ollie Johnston dan Frank Thomas dalam buku "The Illusion of Life : Disney Animation". 12 prinsip animasi terdiri dari:

\section{Solid Drawing}

Dasar utama tentang animasi adalah menggambar. Menggambar memiliki peranan sebuah animasi, khususnya animasi klasik ditinjau dari proses maupun hasilnya. Solid Drawing adalah kemampuan untuk menggambar karakter dalam berbagai angle sehingga karakter tersebut terlihat bervolume dan konsisten dalam setiap frame animasi. Segala atribut seperti mata, pakaian, aksesoris, dan apapun yang menempel dengan si karakter tetap konsisten letak dan bentuknya. Menggambar bisa menjadi sebuah observasi dalam pemahaman terhadap anatomi, komposisi, berat, keseimbangan, dan pencahayaan. 


\section{Timing \& Spacing}

Animator Disney, Grim Natwick, mengatakan, "Animasi adalah tentang timing dan spacing" Timing yaitu ketika animator menentukan waktu kapan sebuah gerakan harus dilakukan. Spacing yaitu menentukan percepatan dan perlambatan dari bermacam-macam gerak.

\section{Squash \& Stretch}

Prinsip animasi yang satu ini mengupayakan efek lentur pada karakter seolah-olah memuai dan menyusut sehingga memberikan efek yang lebih hidup. Penerapan prinsip ini akan memberikan efek dinamis terhadap gerakan sebuah karakter atau benda hidup.

1. Anticipation

Prinsip Anticipation bisa dikatakan sebagai persiapan gerak atau ancang-ancang. Sebelum melakukan gerakan yang besar diperlukan gerakan ancang-ancang agar ada gaya yang mendorong gerakan tersebut.

2. Slow In \& Slow Out

Prinsip animasi Slow In \& Slow Out menegaskan bahwa setiap gerakan memiliki kecepatan dan kelambatan yang berbeda. Slow in terjadi jika sebuah gerakan diawali secara lambat kemudian menjadi cepat. Slow out terjadi jika sebuah gerakan yang relatif cepat kemudian melambat.

3. Arcs

Sistem pergerakan karakter yang ada biasanya bergerak mengikuti pola atau dikenal dengan Arcs. Hal ini dibuat agar karakter bergerak secara smooth dan realistik karena pergerakannya mengikuti sebuah jalur yang sudah dibuat, misalnya lingkaran, elips, atau parabola.

4. Secondary Action

Secondary action ada dibuat untuk memperkuat gerakan pertama agar terlihat lebih realistis. Kemunculannya berfungsi memberikan emphasize yang tidak dimaksudkan menjadi pusat perhatian.

5. Follow Through \& Overlapping Action

Follow through bisa digunakan untuk membuat bagian tubuh tertentu tetap bergerak meskipun sebuah karakter berhenti bergerak. Misalnya setelah melompat, rambut karakter tetap bergerak. Overlapping action secara mudah bisa dianggap sebagai gerakan salingsilang. Maksudnya, adalah serangkaian gerakan yang saling mendahului (overlapping).

6. Straight Ahead \& Pose to pose

Ada dua cara yang bisa dilakukan animator dalam membuat animasi, yaitu straight ahead action dan pose to pose. Untuk straight ahead action, seorang animator membuat animasi dengan cara menggambar satu per satu dan dilakukan dengan seorang diri hingga selesai. Sedangkan pose to pose adalah pembuatan animasi yang dikerjakan hanya dengan menggambar keyframe-keyframe tertentu saja.

7. Staging

Prinsip animasi staging meliputi bagaimana lingkungan dibuat untuk mendukung suasana atau 'mood' yang ingin dicapai dalam sebagian atau keseluruhan scene. Biasanya berkaitan dengan posisi kamera pengambilan gambar.

8. Appeal

Setiap animasi atau studio animasi memiliki gaya visualnya masing-masing. Misalnya saja kamu bisa membedakan gaya animasi buatan Jepang, Disney, atau Dreamworks walaupun melihat dengan sekilas. Hal ini karena mereka mampu memiliki appeal atau gaya tersendiri dalam pembuatan karakter animasi.

9. Exaggeration

Prinsip animasi exaggeration mengupayakan untuk mendramatisir animasi dalam bentuk rekayasa gambar yang hiperbolis di mana pembuatannya dilakukan untuk keperluan komedik. 


\section{Teori Bentuk Dasar}

Pesan visual harus jelas agar efektif dan mengeksplorasi siluet karakter dalam sebuah tahap awal. Tahap desain memudahkan untuk memvalidasi keterbacaan karakter tersebut sejak awal prosesnya, bentuk keseluruhan dapat berbicara kepribadian karakter. 3 Bentuk utama terdiri dari lingkaran, bentuk lengkung dan melingkar dianggap paling ramah karena tidak tajam atau berbahaya sudut. Bentuk melingkar di alam memiliki kecenderungan lembut dan tidak berbahaya serta menimbulkan rasa suka karakter. Banyak dari protagonis paling terkenal dirancang dengan konsep melingkar (Solarski 2012: 180). Kotak, Bentuk seperti persegi berhubungan dengan garis vertikal dan horizontal lurus yang mengomunikasikan kekuatan, stabilitas dan kepercayaan diri. Kotak bisa jadi besar dan menakutkan atau nyaman dan kikuk. Mereka sering menggambarkan karakter tabah yang dapat diandalkan dan biasa digunakan pahlawan super atau yang berat (Bancroft 2006: 34). Dan segitiga, Segitiga berhubungan dengan garis diagonal dan kuat, sudut dan merupakan yang paling dinamis dari ketiganya bentuk. Orang jahat dan penjahat seringkali didasarkan pada konsep segitiga yang dominan tampak jahat dan paling sering berkomunikasi dengan agresi (Bancroft 2006: 35). Ini bentuk yang paling berlawanan dengan lingkaran dan sering digunakan untuk antagonis.

\section{Teori Warna}

Warna termasuk salah satu unsur keindahan dalam seni dan desain selain unsur-unsur visual yang lain (Sulasmi Darma Prawira, 1989: 4). Lebih lanjut, Sadjiman Ebdi Sanyoto (2005: 9) mendefinisikan warna secara fisik dan psikologis. Warna secara fisik adalah sifat cahaya yang dipancarkan, sedangkan secara psikologis sebagai bagian dari pengalaman indera penglihatan.

Dalam sebuah desain, warna adalah salah satu media paling efektif untuk membangun mood dalam membuat suatu proyek desain. Penggunaan warna yang tepat adalah inti dari proyek kali ini, agar desain yang dibuat tidak membawa orang kepada persepsi yang salah mengenai isi dari media visual yang dibuat. Menurut Lesa Sawahata dalam bukunya Color Harmony, Workbook, proses implementasi warna dalam desain dibagi menjadi empat, yaitu : mendefinisikan mood dan tujuan dari proyek kerja kita, kemudian memilih warna yang dapat mengekspresikan mood dengan tepat, selanjutnya mencoba bermain-main dan bereksperimen dengan berbagai variasi tema warna, terakhir adalah mengimplementasikan pemilihan warna ke dalam skema warna terbaik.

\section{Cyberbullying}

Cyberbullying (perundungan dunia maya) ialah bullying/perundungan dengan menggunakan teknologi digital. Hal ini dapat terjadi di media sosial, platform chatting, platform bermain game, dan ponsel. Adapun menurut Think Before Text, cyberbullying adalah perilaku agresif dan bertujuan yang dilakukan suatu kelompok atau individu, menggunakan media elektronik, secara berulang-ulang dari waktu ke waktu, terhadap seseorang yang dianggap tidak mudah melakukan perlawanan atas tindakan tersebut.

Cyberbullying merupakan perilaku berulang yang ditujukan untuk menakuti, membuat marah, atau mempermalukan mereka yang menjadi sasaran. Contohnya termasuk:

1. Menyebarkan kebohongan tentang seseorang atau mem-posting foto memalukan tentang seseorang di media sosial

2. Mengirim pesan atau ancaman yang menyakitkan melalui platform chatting, menuliskan kata-kata menyakitkan pada kolom komentar media sosial, atau mem-posting sesuatu yang memalukan/menyakitkan.

3. Meniru atau mengatasnamakan seseorang (misalnya dengan akun palsu atau masuk melalui akun seseorang) dan mengirim pesan jahat kepada orang lain atas nama mereka.

4. Trolling - pengiriman pesan yang mengancam atau menjengkelkan di jejaring sosial, ruang obrolan, atau game online

5. Mengucilkan, mengecualikan, anak-anak dari game online, aktivitas, atau grup pertemanan

6. Menyiapkan/membuat situs atau grup (group chat, room chat) yang berisi kebencian tentang seseorang atau dengan tujuan untuk menebar kebencian terhadap seseorang 
7. Menghasut anak-anak atau remaja lainnya untuk mempermalukan seseorang

8. Memberikan suara untuk atau menentang seseorang dalam jajak pendapat yang melecehkan

9. Membuat akun palsu, membajak, atau mencuri identitas online untuk mempermalukan seseorang atau menyebabkan masalah dalam menggunakan nama mereka

10. Memaksa anak-anak agar mengirimkan gambar sensual atau terlibat dalam percakapan seksual.

\section{Dampak Kepada Korban Cyberbullying}

1. Menarik Diri Dari Lingkungan Sosial

Kondisi psikologis korban cenderung mengalami kecemasan dan ketakutan. Mereka tidak ragu menarik diri dari lingkungan sosial. Contohnya, banyak kasus bullying di jejaring sosial yang dialami anak sekolah. Akhirnya membuat sang anak depresi, mengisolasi diri karena malu, dan memilih putus sekolah.

2. Perasaan Dikucilkan Lingkungan

Cyber bullying memang terjadi melalui internet atau jejaring sosial. Namun, orang-orang yang berada di lingkungan nyata sekeliling korban dapat melihatnya. Terlebih lagi berbagai komentar jahat yang ditujukan kepada korban. Hal ini membuat orang sekitar turut menyerang korban dalam kehidupan nyata. Akhirnya, korban cyber bullying dikucilkan oleh masyarakat dan mendapat perlakuan kurang menyenangkan.

3. Kesehatan Fisik dan Mental Terganggu

Bullying yang dilakukan secara terus menerus melalui jejaring sosial oleh orang dikenal maupun tidak dikenal akan mendatangkan stress. Ujung-ujungnya perasaan memendam depresi, rasa cemas, dan kehilangan kepercayaan diri mendatangkan gangguan posttraumatic stress disorder (PTSD). Tentunya pengaruh PTSD tidak mengenal usia. Bahkan pada orang dewasa efeknya stimuli sistem kekebalan tubuh menjadi terganggu.

4. Depresi dan Ingin Bunuh Diri

Korban cyber bullying sering kali merasakan marah, takut, terluka, tidak berdaya, malu, putus asa, dan terisolasi. Apabila kondisi ini terjadi berulang-ulang dan semakin parah akan menyebabkan perasaan ingin mengakhiri hidupnya.

\section{Three Act Structure}

Dalam penulisan cerita, penulis menggunakan three act structure sebagai struktur cerita. Three Act Story Structure adalah prinsip lama yang dianut secara luas dalam teknik storytelling. Three Act Story Structure terbagi menjadi 3 bagian, yaitu:

Act I: Setup Tahap pertama adalah semua karakter utama dari cerita diperkenalkan, tempat mereka tinggal, dan konflik yang akan menggerakan cerita ke depan.

Act II: Konfrontasi Di tahap ini, adalah bagian paling lama dan panjang yang terjadi antara babak pertama dan ketiga. Untuk beberapa penulis skenario, Act II adalah yang paling sulit untuk diperas. Pada titik ini, penulis telah menciptakan bingkai yang kokoh untuk narasinya. Penulis menghadapi tantangan untuk menjaga cerita terus berlanjut dan tidak membosankan para penonton. Satu hal agar cerita tidak membosankan adalah menciptakan subplot. Subplot adalah sebuah cerita kecil dari narasi utama. Memang, tidak selalu terhubung ke alur utama, tetapi masih relevan dalam keseluruhan narasi dan sering dikaitkan dengan tema sentral.

Act III: Resolution Tahap terakhir, Act III Resolution menyajikan konfrontasi akhir dari film dan kesimpulan. Act III berisi momen yang sering dilabeli konfrontasi antara pahlawan dan penjahat, perselisihan antara yang baik dan yang jahat, atau, sebuah ending yang sangat twist dan tidak sesuai dengan keinginan penontonnya.

\section{HASIL DAN PEMBAHASAN Hasil Observasi}




\section{Studi Gerak Cartoony Pada Animasi Berjudul Spookiz}

Observasi penulis lakukan melalui melihat animasi series berjudul Spookiz sebagai sumbernya. Penulis mencoba mengamati setiap gerakan animasi pada animasi Spookiz dan menganalisa bagaimana membuat animasi dengan gaya cartoony. Animasi yang dibuat oleh Korea Selatan ini bercerita mengenai 5 monster yang mulai menjalani hari mereka di malam hari di sebuah sekolah yang sudah sepi untuk menghindari manusia. Animasi ini mengaplikasikan exaggeration dengan sangat sehingga terlihat cartoony, dan juga membuat animasi tersebut appealing.

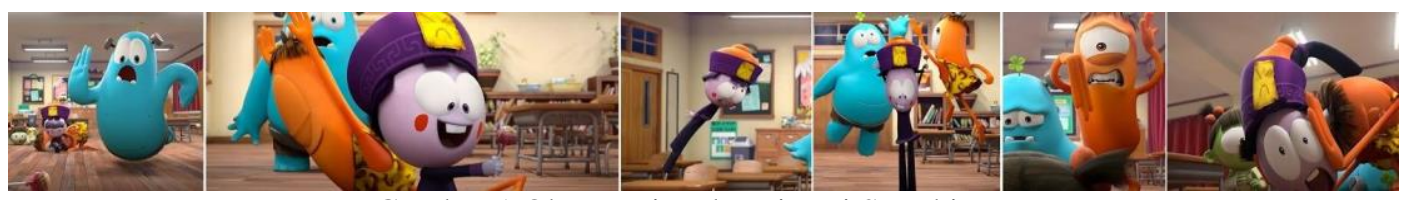

Gambar 1 Observasi pada animasi Spookiz

Sumber: Spookiz: The movie

Gambar di atas merupakan beberapa contoh exaggeration yang penulis ambil dari Spookiz: The Movie. Dapat terlihat bahwa banyak gerakan pada karakter yang dibuat bagianbagian tertentu seperti badan, jari, dan lengan menjadi stretch ataupun squash berlebihan sehingga membuat badannya deform (bentuk tidak sesuai anatomi tubuh aslinya) untuk menghasilkan gerakan exaggeration. Meskipun badannya deform karakter tetap tidak terlihat aneh karena bagian ini hanya berlangsung selama beberapa frame saja sehingga cukup sulit untuk melihatnya dengan jelas.

Yang membuat exaggeration bisa membuat suatu animasi terlihat cartoony adalah bentuk karakter yang menjadi deform tidak sesuai bentuk aslinya dan dalam dunia nyata hal tersebut tidak dapat dilakukan. Maka dari itu gerakan animasi yang cartoony dapat menjadi daya tarik tersendiri.

\section{Studi Kasus}

Dalam Studi kasus penulis mengamati desain karakter kartun ikonik yang dibuatkan desain ulang untuk film live action. Penulis mengambil 2 kasus yang berbeda. Yang pertama adalah karakter Sonic pada film Sonic: The Hedgehog, dan yang kedua adalah karakter Pikachu pada film Pokémon: Detective Pikachu. Kesamaan dari 2 karakter ini adalah desain kartunnya yang ikonik dan banyak digemari oleh penontonnya. Serta kedua karakter ini memiliki versi 3D dimana keduanya dibuat menjadi film live-action. Akan tetapi yang kedua karakter tersebut adalah desain 3D yang memiliki respons berbeda dari penonton. Maka dari itu penulis akan membahas alasan dibalik respons positif dan negatif yang didapat dari kedua karakter tersebut.

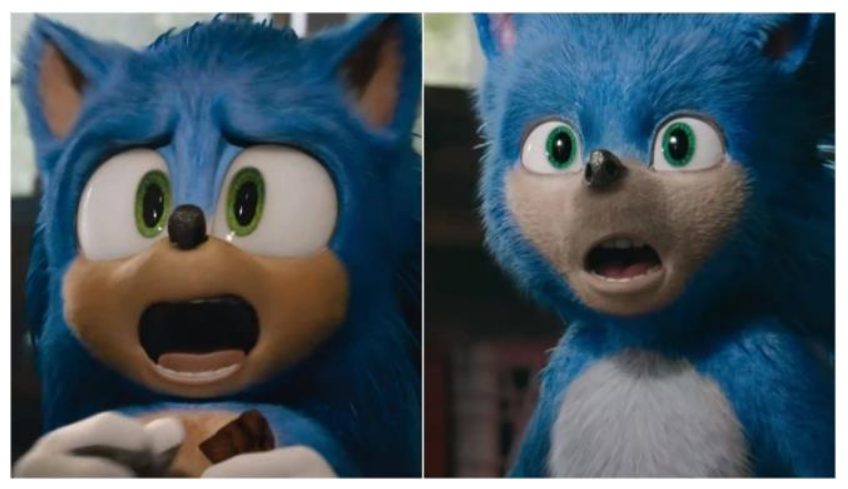

Gambar 2 Perbandingan desain Sonic: The Hedgehog Sumber gambar: Paramount Pictures 
Pada trailer film Sonic: The Hedgehog terdapat 2 versi, dimana trailer pertama Sonic dibuat menjadi realistik. Karena film ini adalah live-action dimana para karakter akan berinteraksi dengan manusia asli, direktur ingin membuat karakter kartun Sonic menjadi serealistis mungkin. Akan tetapi timbal balik yang didapat tidak bagus. Banyak penonton yang merasa karakter Sonic menjadi jelek dan menyeramkan. Akibat dari respons yang kurang baik, dibuatlah trailer kedua dengan karakter Sonic yang didesain ulang. Di sini karakter Sonic menjadi semi-realis dan lebih terlihat familiar. Dengan mata yang lebih besar dan bulat, wajah yang lebih bulat, mulut yang dibuat kurang mirip manusia dan lebih sedikit gigi. Dari sini respons penonton menjadi lebih baik dan film dilanjutkan dengan desain kedua dari karakter 3D Sonic, sedangkan untuk karakter Pikachu pada film Pokémon: Detective Pikachu memiliki timbal balik yang baik. Karakter tersebut masih dapat diterima oleh penonton dan mendapat banyak dukungan. Lalu apakah yang membedakan kedua karakter tersebut?

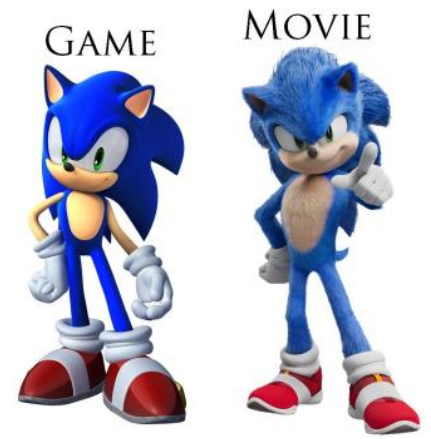

Gambar 3 Desain Sonic di Game dan film Sumber: Google

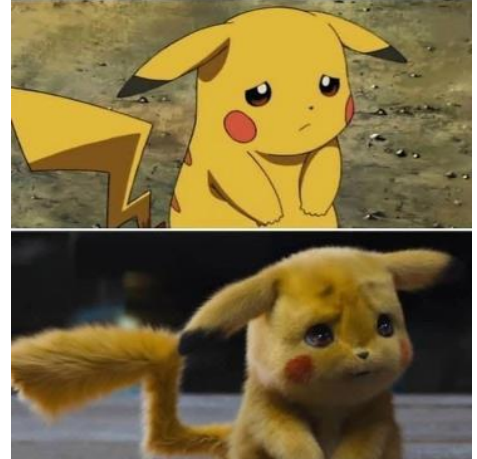

Gambar 4 Desain Pikachu di Game dan Film Sumber: Google

Pertama karakter Sonic yang dibuat pada trailer pertama terlihat terlalu realistis dan desainnya terlihat jauh berbeda dari karakter kartunnya yang ikonik. Bentuknya yang terlalu mirip dengan anatomi manusia dengan bulunya yang berwarna biru membuatnya menjadi terlihat aneh dan menyeramkan. Sedangkan untuk karakter Sonic pada trailer kedua dibuat lebih mirip ke desain karakter kartun originalnya, sehingga proporsinya menuju ke arah style gambar ikonik dan masih terlihat mirip dengan karakter kartun originalnya. Maka dari itu penonton merasa lebih familiar dengan karakter Sonic yang didesain ulang itu. Sama hal nya dengan desain 3D pada karakter pikachu. Untungnya, Pikachu tidak hanya terlihat hebat dalam liveaction, tetapi tetap terasa seperti milik dunia itu. Bentuk dan proporsi karakter tetap utuh hanya dengan beberapa perbedaan yang dibuat pada teksturnya. Meskipun digambarkan dalam liveaction, Pikachu sama imut dan kerennya seperti di game dan anime. Meskipun Pikachu disuarakan oleh pria dewasa, itu tidak menghalanginya menjadi dari karakter lucu yang dikenal dan dicintai penggemar.

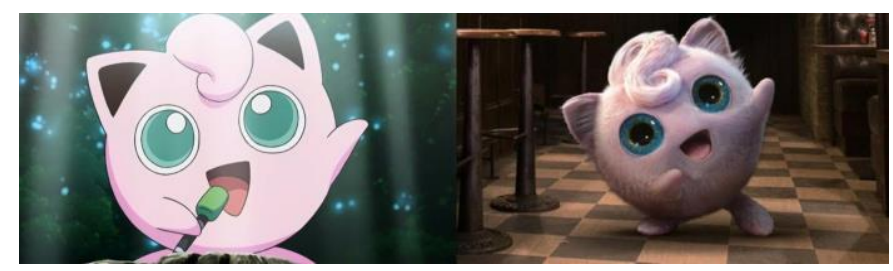

Gambar 5 Desain Jigglypuff di Anime dan Film Live-Action Sumber: Google

Akan tetapi, tidak semua karakter di film Pokémon: Detective Pikachu terlihat bagus. Ada beberapa karakter yang terlihat aneh dan kurang cocok dengan desain karakter anime aslinya. Seperti contohnya pada karakter Jigglypuff. Sangat bagus bahwa Jigglypuff muncul di 
Pokémon: Detective Pikachu, meski hanya sebentar. Pokémon balon bernyanyi ini sudah ada sejak di awal film, jadi sudah pasti layak mendapat adegan dalam film. Namun, ada satu elemen kunci pada desainnya yang tidak cukup bagus: bulunya. Jigglypuff digambarkan dengan bulu di seluruh tubuhnya, yang tidak mewakili desain aslinya dengan baik. Jigglypuff yang pada dasarnya terbuat dari balon, akan lebih masuk akal untuk memberikan tekstur kulit yang licin pada tubuhnya. Hasilnya tidak buruk, karena Jigglypuff masih terlihat baik-baik saja, tetapi bulunya tampak seperti mengarah ke arah yang salah.

Kesimpulan yang bisa penulis ambil adalah karakter kartun yang ikonik bila akan dibuat menjadi karakter 3D, desain karakter tersebut harus dibuat mirip dengan karakter aslinya dari segi bentuk dan proporsi serta detail yang menjadi ciri khas karakter tersebut. Jika dibuat terlalu menyimpang dari karakter aslinya, ciri khas dari karakter ikonik itu akan hilang dan menjadikan karakter 3D yang didesain itu terlihat tidak familiar hingga aneh.

\section{Hasil Wawancara}

Orang pertama yang diwawancarai oleh penulis adalah Budi H. seorang senior animator di salah satu studio animasi terbesar di Indonesia, Infinite Studios. Dengan berbagai partisipasinya dalam mengerjakan animasi luar negeri seperti Vampirina, Christmas Letter, Kangaroo Beach, Made by Maddie, Ollie dan banyak lagi. Dari wawancara ini penulis mencoba fokus bertanya seputar style animasi cartoony. Dari wawancara ini dapat disimpulkan beberapa hal. Di antaranya adalah:

1. Untuk gaya animasi cartoony akan lebih menarik jika menggunakan gaya animasi dengan timing snappy dari pada gaya animasi yang organik seperti gerakan manusia di dunia nyata.

2. Sebuah karakter akan terlihat lebih appealing jika terdapat secondary action seperti di bagian rambut atau ekornya.

3. Hal pertama untuk menarik penonton adalah visual dari karakter desainnya.

4. Meskipun sebuah karakter tidak memiliki kalimat dialog, dia bisa tetap terlihat ekspresif dilihat dari bagaimana pose tubuh dan gerakannya.

Wawancara kedua dilakukan bersama Teresa D. seorang mahasiswi psikologi di Universitas Sanata Dharma. Dari wawancara ini penulis menanyakan hal seputar cyberbullying sebagai pendukung cerita. Dari wawancara ini dapat disimpulkan beberapa hal. Di antaranya adalah:

1. Cyberbullying merupakan kegiatan yang sengaja dan berulang kali dilakukan seseorang dengan tujuan menyakiti orang lain dengan menggunakan teknologi seperti telepon atau komputer.

2. Motif yang mendasari seseorang untuk melakukan Cyberbullying banyak sekali. Di antaranya bisa saja karena ada dendam, rasa marah atau perasaan frustrasi dari pelaku cyberbullying terhadap korban.

3. Cyberbullying mempunyai risiko mengalami masalah kesehatan mental dan penggunaan narkoba, yang bisa memicu percobaan bunuh diri.

4. Akan sulit untuk menghentikan cyberbullying karena cyberbullying dampak buruk dari adanya teknologi saat ini, sedangkan teknologi terus berkembang dan perkembangannya sangat cepat. Cyberbullying hanya bisa diminimalkan intensitas terjadinya.

\section{Hasil Perancangan Cerita dan Sinopsis Cerita}

Internet yang dulunya adalah tempat yang banyak membantu kehidupan manusia sekarang telah tersebar kejahatan di dalamnya, salah satunya adalah cyberbullying. Dampak yang diberikan oleh cyberbullying sudah melewati batas, maka dari itu muncullah seorang karakter penjaga portal komentar bernama Kai. Demi menghentikan cyberbullying yang mulai menyebar di portal komentar, Kai terjun ke dalam internet untuk memburu dan membunuh semua komentar jahat itu sebelum memakan lebih banyak korban. Meskipun Kai kuat dan sangat percaya diri dengan kemampuan yang ia miliki, mengalahkan semua musuh sendirian bukanlah hal yang mudah. Maka dari itu diperlukan bantuan dari orang lain termasuk salah 
satunya Vivi, teman paling setia Kai. Di dalam internet ini mereka bertemu dengan berbagai macam komentar jahat dan mereka berdua bertarung mati-matian untuk menyebar lebih banyak kasih sayang dan juga mengalahkan semua musuh yang ada sebelum para komentar jahat itu menyerang portal komentar.

\section{Uraian Cerita}

Dalam penulisan cerita, penulis menggunakan Three Act Structure sebagai struktur cerita. Seperti yang dijelaskan pada landasan teori bahwa Three Act Structure dibagi menjadi 3 bagian utama, yaitu Act 1, Act 2, dan Act 3. Di sini penulis akan menguraikan ide cerita dari Sinopsis yang sudah dibuat ke dalam bentuk Three Act Structure.

Act 1: Setup

Exposition: Penulis menggunakan narasi untuk memperkenalkan siapa karakter utamanya, apa yang ia lakukan, kekuatan apa yang dimilikinya, dan menjelaskan bagaimana internet yang selalu dipakai kapan pun dan di mana pun sangat berguna bagi kehidupan manusia.

Inciting Incident: Narasi akan menjelaskan bahwa selain dampak positif yang diberikan oleh internet, terdapat juga dampak negatifnya. Di sini akan ditunjukkan kasus-kasus dari cyberbullying dan dampaknya kepada korban.

\section{Act 2: Konfrontasi}

Midpoint: Karakter utama memasuki dunia internet dan menggambarkan bagaimana keadaan di dalam internet dan bagaimana komentar jahat yang menjadi salah satu penyebab cyberbullying itu dapat terjadi.

Rising point: Di sini karakter utama akan bertemu dengan berbagai musuh jahat dan akan melawan serta membunuh mereka semua.

\section{Act 3: Resolution}

Climax: Di sini karakter utama akan bertemu dengan musuh yang lebih kuat darinya hingga sangat mustahil untuk mengalahkannya.

Denouement: Karakter dapat mengalahkan semua musuhnya dengan bantuan teman-temannya. Dan mereka kembali menjaga portal komentar dari komentar jahat.

\section{Penulisan Judul}

Judul film animasi pendek yang penulis ciptakan untuk sementara adalah cyber heroes, hal ini berkaitan dengan isi cerita yang mengandung tema cyberbullying dan karakter pahlawan di dalamnya.

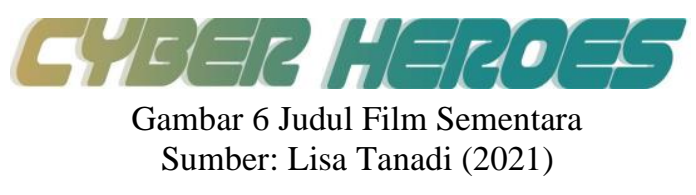

Dikarenakan film animasi pendek ini berhubungan dengan cyber yang arti nya adalah suatu istilah yang digunakan orang untuk menyatakan sesuatu yang berhubungan dengan internet atau dunia maya. Maka penulis ingin menciptakan font judul yang mempresentasikan teknologi, yang tak lain adalah font dengan garis yang jelas dan simpel sehingga enak untuk dibaca. Font yang penulis pilih adalah 1st Enterprises Cond Superltal, dengan alasan selain tulisannya dapat terlihat jelas, ia juga memiliki ujung sudut yang melengkung sehingga tidak terlalu kaku dan juga fontnya yang tebal cocok digunakan sebagai judul untuk menarik perhatian.

\section{Perancangan Tokoh Karakter Bentuk (Shape Language)}

Shape Language adalah konsep yang digunakan dalam seni dan animasi untuk mengomunikasikan makna berdasarkan bentuk yang kita kenal. Ketika digunakan dalam 
karakter, objek, dan desain latar belakang, bentuk dapat menceritakan kisah, menunjukkan kepribadian, dan juga respons emosional kepada penonton tanpa menggunakan kata-kata apa pun.

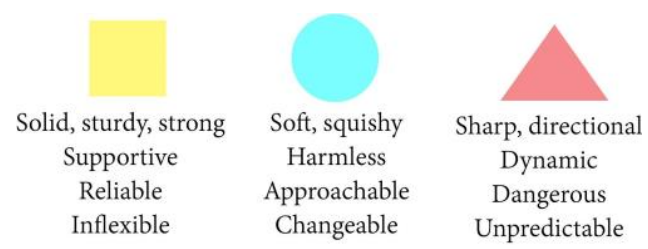

Gambar 7 Gambar Bentuk dan Karakteristiknya

Sumber: Lisa Tanadi (2021)

Meskipun begitu, contoh yang disajikan merupakan pedoman umum. Lingkaran, kotak, dan segitiga tidak selalu berarti satu hal. Seperti yang kita ketahui bentuk dasar diatas terdiri dari garis. Bahkan garis memberikan kesan tertentu.

_ Horizontal
| Vertical
/ Diagonal
) Curved
> Angles

- Constant and stability

- Height and power

- Movement, unstable

- Soft and Safe

- Chaotic, uneasy, speed
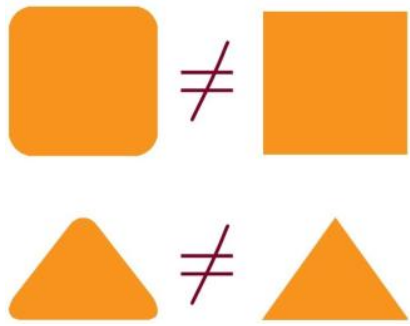

Gambar 8 Gambar Benda Dengan Garis Yang Berbeda Sumber: Lisa Tanadi (2021)

Pada dasarnya kotak dengan garis sudut yang tajam akan memberikan kesan yang kuat, percaya diri, kokoh dan kaku sedangkan kotak dengan sudut melengkung akan memiliki makna yang berbeda. Kotak itu akan tampak lebih lembut, lebih fleksibel. Bentuk lingkaran dikenal orang sebagai bentuk yang lembut, tidak bahaya dan juga lebih mudah didekati. Karakter penjahat yang bulat maupun melingkar dirancang agar terlihat baik tetapi dibalik itu, ia merupakan tokoh jahat. Bentuk melingkar dapat digunakan untuk menyesatkan penonton tentang siapa karakternya. Menambahkan lingkaran ke karakter penjahat dapat menyiratkan tingkat kelemahan mereka dan mengekspresikan bahwa mereka tidak harus terlihat berbahaya untuk menjadi berbahaya.

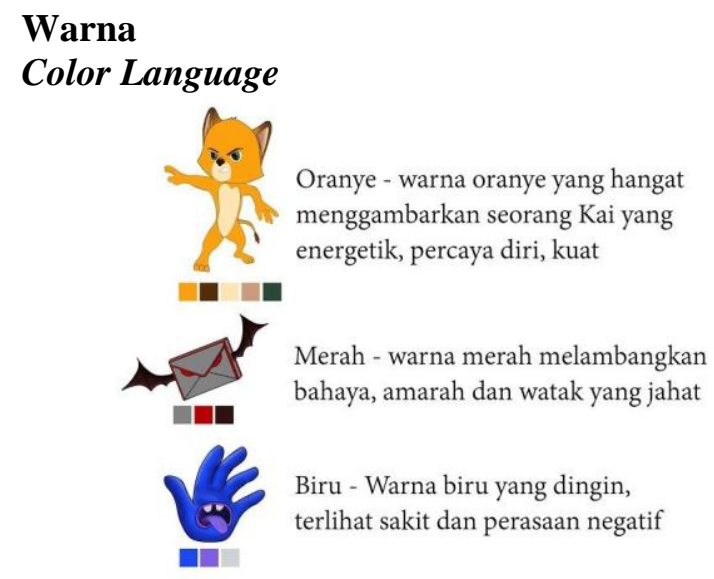

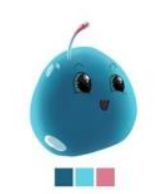

Biru muda - warna biru muda yang jernih seperti air menggambarkan vivi yang fresh, ceria

Pink - warna pink yang identik dengan cinta dan kasih sayang

Merah - warna merah melambangkan



Hitam - Warna hitam yang menggambarkan kegelapan, misteri, dan kematian

Hijau - hijau neon yang dipakai untuk membuat racun.

Gambar 9 Color Language Characters

Sumber: Lisa Tanadi (2021) 
Sebuah objek dapat terlihat berbeda dengan warna yang berbeda pula. Warna dalam desain karakter dapat memberikan mood atau gambaran tertentu yang bisa menceritakan karakteristik dibaliknya.

\section{Color Hierarchy}

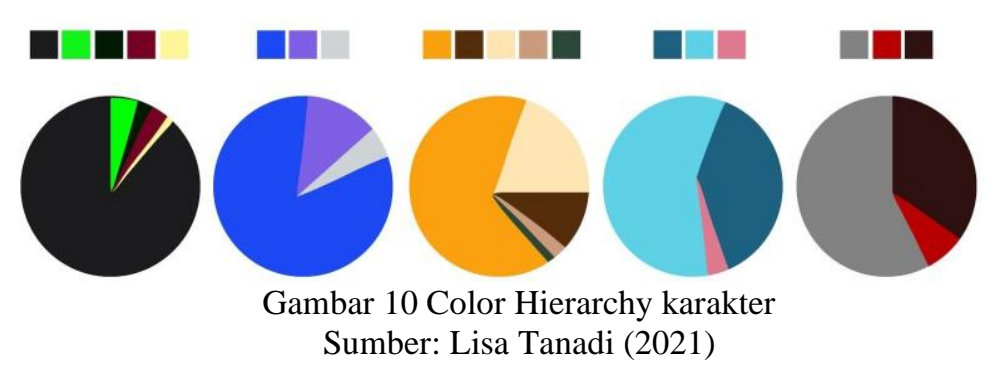

Hierarki warna adalah saat di mana kita memilih satu warna yang dominan, serta warna lainnya sebagai komplementer yang mendukung dan tidak mengganggu atau menutupi warna dominannya.

\section{Desain Visual Karakter}

1. Tokoh utama yang pertama adalah Kai. Kai adalah seorang karakter penjaga portal komentar dari komentar-komentar jahat. Kai memiliki visual yang mirip seperti singa dan rubah. Bentuk dasarnya adalah kotak dengan sudutnya yang melengkung membuat dirinya menjadi pribadi yang sangat percaya diri, bersemangat, tidak mudah putus asa, dan selalu menjunjung tinggi pertemanan. Kai memiliki peranan penting dalam menghentikan cyberbullying di dalam internet.

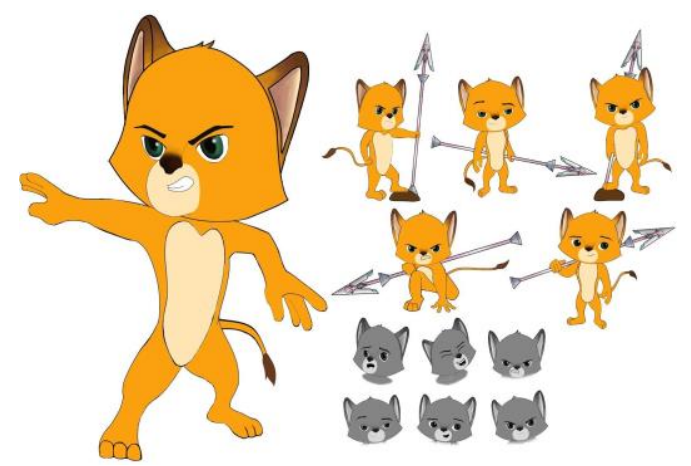

Gambar 11 Desain Karakter Kai

Sumber gambar: Lisa Tanadi (2021)
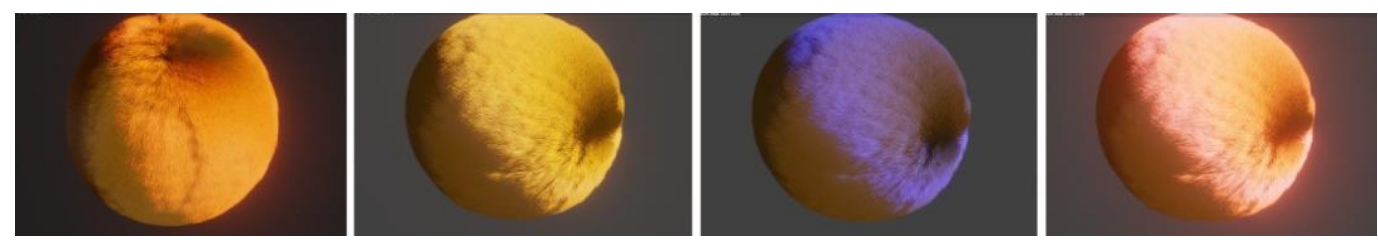

Gambar 12 Gambar Test Render Fur Sumber: Lisa Tanadi (2021)

Penulis mencoba membuat render bulu dari kai menggunakan salah satu software 3D yaitu Blender. Render fur diberikan untuk membuat tekstur dari bulu Kai terlihat realistik dan dapat menambah tingkat estetikanya. Dan juga setiap cahaya yang terpantulkan ke bulu akan memberikan setiap mood yang berbeda. 
2. Karakter utama yang kedua adalah Vivi. Penulis ingin membuat karakter yang imut dan lucu untuk menyeimbangkan karakter Kai. Maka dari itu penulis membuat desain karakter ini berdasarkan bentuk lingkaran dengan bentuk tubuh yang cenderung kecil dan juga mata nya yang besar.

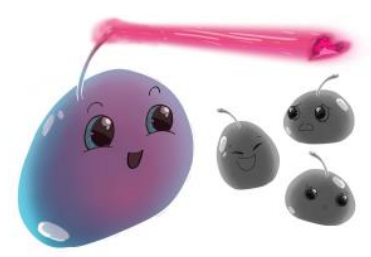

Gambar 13 Desain Awal Karakter Vivi

Sumber: Lisa Tanadi (2021)

3. Karakter penjahat pertama adalah Square Bat. Square Bats memiliki bentuk seperti surat sama seperti namanya Square, bentuk utamanya adalah kotak dengan sayapnya yang memiliki ujung yang tajam. Square Bats menyerang secara berkelompok dan dapat mengeluarkan ultrasonic sound.

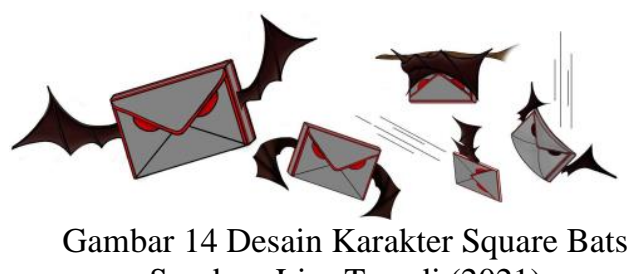

Sumber: Lisa Tanadi (2021)

4. Karakter penjahat kedua adalah Handableg. Seperti namanya, Handableg memiliki bentuk tangan manusia berwarna biru dengan mulut berwarna ungu di telapaknya. Warna biru sendiri adalah warna komplementer dari warna kuning. Sementara warna kuning adalah warna primer yang paling mendekati warna kulit manusia. Warna biru menjadi tolak belakang dengan warna kulit manusia pada umumnya, menjadikan Handableg tidak memiliki hati nurani seperti manusia. Maka dari itu ia menuliskan komentar jahatnya tanpa memikirkan orang yang membacanya. Mulutnya berwarna ungu melambangkan warna mulut orang ketika sedang sakit.

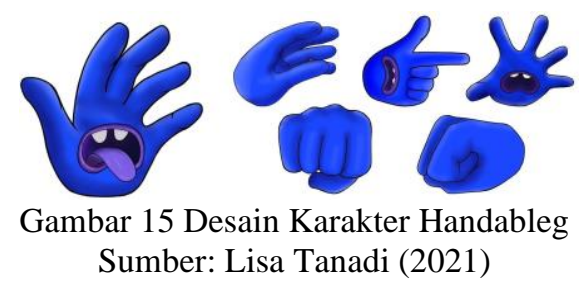

5. Karakter penjahat terakhir dan yang paling kuat adalah Snakeye. Snakeye diambil dari tubuh ular dikarenakan ular merupakan binatang yang mematikan dan menakutkan sehingga banyak dianggap menyeramkan dan dihindari oleh orang. Sedangkan untuk matanya sendiri melambangkan orang-orang yang selalu memperhatikan kita. Setiap kita menulis atau memposting sesuatu di social media, semua orang dapat melihatnya dan merupakan tontonan publik, bahkan bisa meninggalkan jejak digital untuk selamanya. Warna corak hijau neon di tubuh snakeye melambangkan warna hijau yang dipakai untuk membuat racun. Ia dapat menyerang menggunakan bola mata maupun ekornya atau dengan melilitkan mangsanya hingga mati. Tubuhnya besar dan kuat membuatnya tidak mudah untuk dikalahkan. 


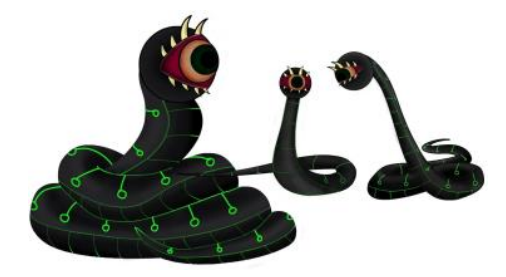

Gambar 16 Desain Karakter Snakeye

Sumber: Lisa Tanadi (2021)

\section{Perancangan Desain Environment}

Terdapat 2 environment yang pertama adalah wifi router yang digunakan oleh karakter utama untuk masuk sebelum ke dalam internet, dan yang kedua adalah di dalam internet. Wifi router dibuat menyerupai isi di dalam wi-fi router yang asli dengan setiap arsitekturnya dibuat menurut referensi dari tiap-tiap partikel yang ada di dalam wifi router.

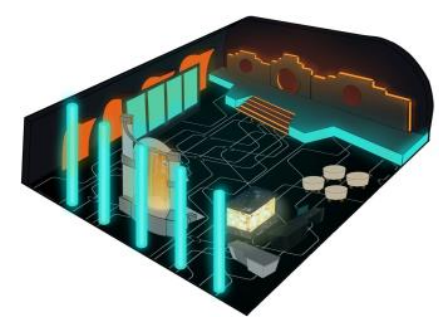

Gambar 17 Desain Environment Router Wi-Fi Sumber: Lisa Tanadi (2021)

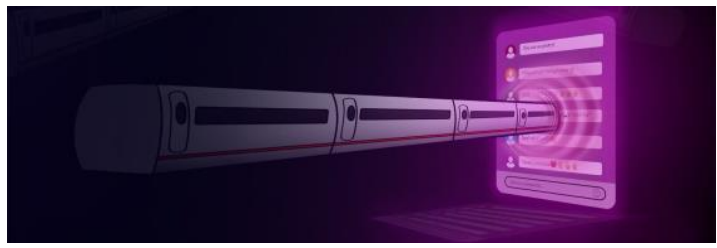

Gambar 18 Desain Environment Inside the Internet Sumber: Lisa Tanadi (2021)

Dalam adegan di dalam internet ini, digambarkan sebagai ruang hampa tanpa batas yang gelap. Di sini akan terdapat 2 titik penting. Yang pertama adalah titik di mana para heroes memasuki ruang internet ini. Dan titik kedua terdapat di sudut ruang tempat portal komentar itu berada. Portal komentar sendiri divisualisasikan sebagai tempat dimana orang-orang meletakkan komentarnya di media social.

\section{Prinsip Dasar Animasi}

Penemuan animasi tidak terlepas dari penemuan prinsip dasar animasi. Dalam pembuatan animasi sendiri, ada 12 prinsip animasi yang diperkenalkan oleh animator Disney, Ollie Johnston dan Frank Thomas dalam buku "The Illusion of Life : Disney Animation". Dengan menerapkan prinsip dasar animasi, penulis mencoba membuat test animasi pada karakter 3D yang sudah ada yaitu Cartoon Guy Rig. Test animasi yang dilakukan berupa test body mechanic karakter yang memakai tongkat sebagai perangkat senjatanya untuk memukul benda yang berada di depannya dengan menggunakan software Autodesk Maya. Dari test animasi ini penulis mendapati bahwa:

1. Prinsip animasi Squash and Stretch mengupayakan efek lentur pada karakter seolah-olah memuai dan menyusut sehingga memberikan efek yang lebih hidup. Penerapan prinsip ini 
dapat dipraktikan pada karakter vivi yang memiliki tubuh yang lentur.

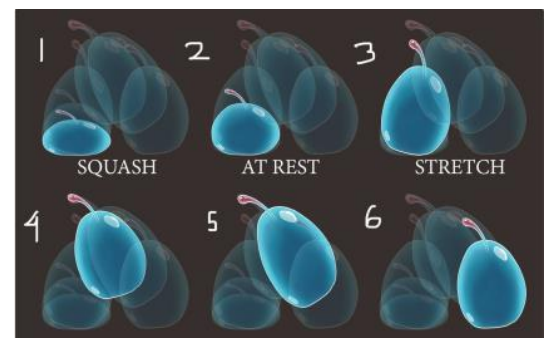

Gambar 19 Squash and Stretch Pada Karakter Vivi Sumber: Lisa Tanadi (2021)

2. Sistem pergerakan karakter yang ada biasanya bergerak mengikuti pola atau dikenal dengan arcs. Hal ini dibuat agar karakter bergerak secara smooth dan realistik karena pergerakannya mengikuti sebuah jalur yang sudah dibuat, misalnya lingkaran, elips, atau parabola. Prinsip ini banyak dipakai untuk gerakan action yang dilakukan Kai.

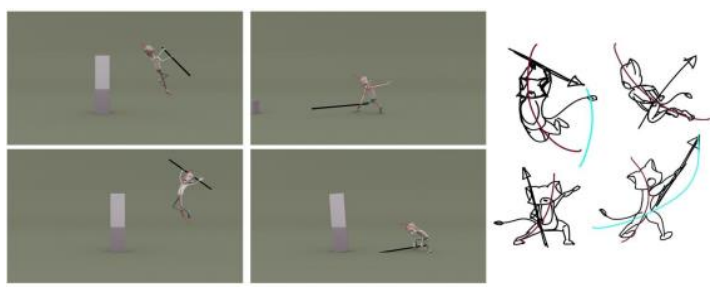

Gambar 20 Arcs Pada Test Animasi Cartoon Guy dan Karakter Kai Sumber: Lisa Tanadi (2021)

3. Prinsip Anticipation bisa dikatakan sebagai persiapan gerak atau ancang-ancang. Sebelum melakukan gerakan yang besar diperlukan gerakan ancang-ancang agar ada gaya yang mendorong gerakan tersebut. Karakter melakukan anticipation pada frame 56 sebelum melompat.

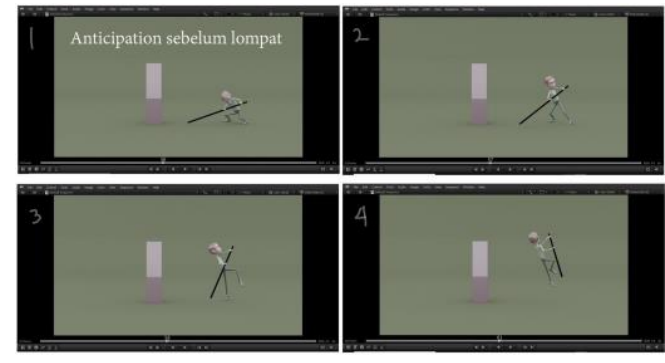

Gambar 21 Anticipation Pada Test Animasi Cartoon Guy

Sumber: Lisa Tanadi (2021)

4. Timing and Spacing pada gambar 2.34 dibawah penulis memberikan contoh gambar per 2 frames. Bisa dilihat pada frame 29 karakter mulai lompat dan melayang dari frame 31, mencapai titik tertinggi pada frame 35 dan masih pada posisi melayang diatas udara hingga 39 lalu mendaratkan kakinya pada frame 41.

5. Slow In and Slow Out Pada saat karakter melompat di frame 29 dan hendak menuju titik tertinggi saat melayang, karakter menggunakan prinsip slow in pada frame 31 hingga 34 dimana gerakannya melambat sebelum menyentuh titik tertinggi di frame 35 dan 
menggunakan prinsip slow out saat setelah karakter jatuh akibat gravitasi pada frame 36 hingga 39, lalu mendaratkan kakinya pada frame 41.

6. Prinsip timing \& spacing dan juga prinsip slow in \& slow out sangat penting dan harus diaplikasikan secara berdampingan untuk menghasilkan animasi yang enak dilihat. Jika tidak menggunakan prinsip ini dengan benar animasi yang dihasilkan dapat terlihat floaty maupun jerky.

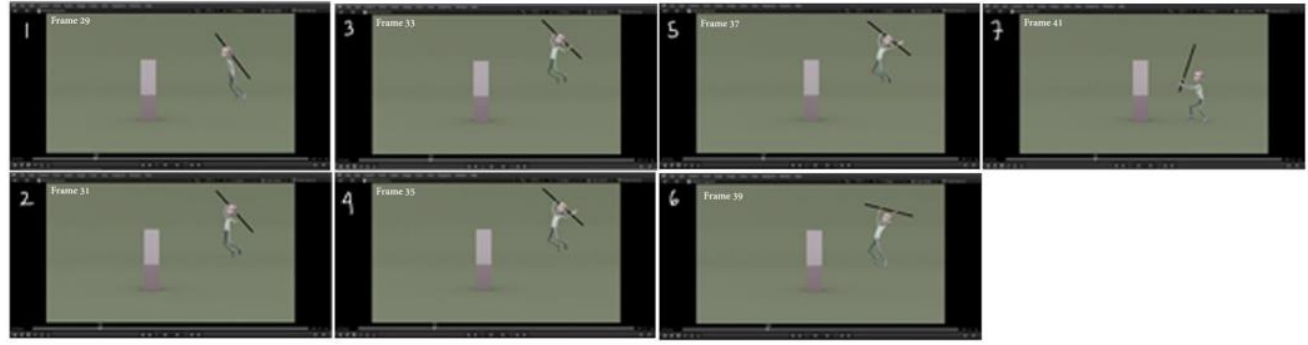

Gambar 22 Test Animasi Cartoon Guy

Sumber: Lisa Tanadi (2021)

7. Prinsip animasi pose to pose dilakukan pada tahap blocking. Pose to pose adalah pembuatan animasi yang dikerjakan hanya dengan menggambar keyframe tertentu saja. Pada blocking karakter, penulis membuat pose-pose penting untuk menghasilkan kesinambungan antar gerakannya. Tahap blocking ini dilakukan sebelum masuk ke tahap splining dan finalling.

8. Follow through bisa digunakan untuk membuat bagian tubuh tertentu tetap bergerak meskipun sebuah karakter berhenti bergerak. Overlapping action secara mudah bisa dianggap sebagai gerakan saling-silang. Maksudnya, adalah serangkaian gerakan yang saling mendahului (overlapping). Pada frame 70 badan serta tangan karakter mulai perlahan bergerak diam. Dan pada frame 71 tangan sudah benar-benar diam sementara jari-jarinya masih bergerak hingga frame 74 .

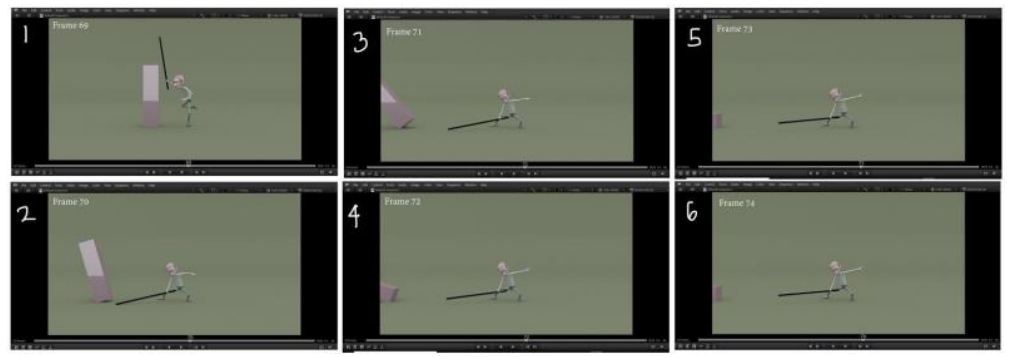

Gambar 23 Follow Through dan Overlapping Action pada Cartoon Guy Rig Sumber: Lisa Tanadi (2021)

\section{SIMPULAN}

Ide awal penulis melakukan riset ini adalah membuat film animasi pendek 3D dengan menggunakan tema cyberbullying. Melihat maraknya cyberbullying di internet yang ada dimana-mana membuat penulis mengkhawatirkan dampaknya yang cenderung buruk. Banyak orang yang menderita hingga bunuh diri akibat cyberbullying ini. Maka dari itu penulis ingin menyampaikan pesan untuk menghentikan cyberbullying melalui film animasi pendek. Pada riset ini penulis telah menyelesaikan ide cerita dan mengembangkannya menjadi premis, logline dan juga sinopsis pendek. Lalu penulis juga sudah menyelesaikan pembuatan desain karakter, baik karakter utama maupun karakter pendukung, environment dan juga properti. Selama pelaksanaan riset, penulis banyak belajar mengenai desain karakter. Mulai dari bagaimana bentuk visual dapat menggambarkan karakteristik, dan juga bagaimana garis itu berperan penting dalam mempresentasikan karakteristik tersebut. Dan tak kalah penting, ada berbagai makna warna yang dapat membantu karakteristik dari desain karakter itu dapat bersinar.

Dalam pembuatan animasi pendek, tentu gerak animasi menjadi poin penting dalam pembuatan film ini. Maka dari itu penulis ingin membuat animasi dengan gaya animasi 
cartoony. Melihat gaya animasi cartoony belum banyak digunakan di animasi buatan Indonesia, penulis ingin menunjukkan ke penonton bagaimana gerak animasi cartoony ini sangat menarik dan memiliki daya tarik tersendiri. Penulis menggunakan animasi series berjudul Spookiz sebagai referensi gerak. Gerak animasi cartoony membutuhkan berbagai macam pengaplikasian 12 prinsip dasar animasi dengan baik dan benar agar gerak yang dihasilkan dapat terlihat bagus.

\section{DAFTAR PUSTAKA}

Bancroft, T. (2006). Creating characters with personality. New York : Random House Inc.

Besley, S., \& Brigham, E. F. (2008). Essentials of managerial finance. United States of America: Thomson South-Western.

Christopher, L., \& Lauren, K. W. (2005). Pemasaran jasa (terjemahan). Jakarta: Gramedia.

Darmaprawira, S. (1989). Warna sebagai salah satu unsur seni dan desain. Jakarta: Departemen Pendidikan dan Kebudayaan Direktorat Jenderal Pendidikan Tinggi Proyek Pengembangan Lembaga Pendidikan Tenaga Pendidikan.

Griezel, L., Craven, R.G., Yeung, A.S., \& Finger, L.R. (2008). The development of a multidimensional measure of cyberbullying. Brisbane: Australian Association for Research in Education.

Gunawan, B. B. (2013). Nganimasi Bersama Mas Be. Jakarta: Elex Media Komputindo.

Napitupulu, F. H., \& Tua, P. M. (2012). Perancangan dan pengujian alat pengering kakao dengan tipe cabinet dryer untuk kapasitas 7, $5 \mathrm{~kg}$ per-siklus. Jurnal Dinamis, (10).

Napitupulu, Farel H., Tua, Putra Mora. (2012). Perancanagan dan Pengujian Alat Pengering Kakao dengan Tipe Cabinet Dryer untuk Kapasitas 7,5 kg Per-Siklus. Jurnal Dinamis, II (10).

Prakosa, G. (2012). Nganimasi, bersama Mas Be. Jakarta: PT. ELEX Media Komputindo.

Sanyoto, S. E., \& Sadjiman, D. (2005). Dasar-dasar tata rupa dan desain. Yogyakarta: Arti Bumi Intaran.

Solarski, C. (2012). Drawing basics and video game art: Classic to cutting-edge art techniques for winning video game design. Watson-Guptill. 